\title{
GONDOLATOK A PERIFÉRIAKÉPZŐDÉS TÖRTÉNETI ELŐZMÉNYEIRŐL ÉS KÖVETKEZMÉNYEIRŐL
}

\author{
(Some Thoughts About the Historical Preliminaries and \\ Consequences of the Formation of Peripheries)
}

\author{
BARANYI BÉLA
}

Kulcsszavak:

perifériaképzödés centrum-periféria viszonyrendszer belsö-és külsö periféria Alfóld

Az egyetemes történeti összefïggéseket is érintố tanulmány a magyarországi perifériaképzödés történelmi elözményeit és következményeit igyekszik bemutatni. A szerzö a centrum-periféria viszonyrendszer történelmi dimenzióit tárgyalva részletesen elemzi a belsö (pl. Közép-Tiszavidék) és külsö (határ menti) perifériák sajătosságait, $s$ mindenekelốt az Alföld nagyrégió példáján keresztül is feltárja a hátrányos, esetenként a halmozottan hátrányos helyzet jellemzöit, utalva a területi egyenlötlenségek csökkentésének és az elmaradott térségek felzárkóztatásának lehetöségeire.

\section{A centrum-periféria viszonyrendszer történeti dimenziói}

$$
\text { Középkori „elöjáték”" - az új európai munkamegosztás és Magyarország }
$$

Eltekintve a centrum-periféria viszonyrendszer, illetőleg a területi konfliktusok és a periféria-problémák általános értelmezésétől, a figyelmet ezúttal erőteljesebben a fogalompár második felére, mindenekelött a perifériaképződés történelmi elözményeire, következményeire és sajátosságaira irányítjuk. A történeti gyökereket illetỏen Magyarország esetében is a régmúltba, egészen a 15-16. század fordulójáig kell visszanyúlni. A késő középkorban, az amerikai Immanuel Wallerstein jó néhány éve ismertté és divatossá vált, sokszor idézett elmélete szerint a 16. század elején létrejött az ún. „európai világgazdaság”. Az új világgazdaság Wallerstein álláspontja szerint már nem egy nagy birodalom jegyeit viselte magán, hanem egy olyan hatalmas kiterjedésủ térség sajátosságait, amelyek a különféle társadalmi rendszereknek a világ elött addig nem ismert fajtáját képviselték. Az új, formálódó „világgazdaság" legfontosabb megkülönböztető jegye, mintegy differencia specifikája volt immár, hogy elsősorban már gazdasági, nem pedig politikai entitást képviselt a korabeli birodalmakkal, városállamokkal és a születö félben lévö kvázi nemzetállamokkal szemben. Az új „Világ-rend” legfőbb sajátossága már nem a teruiletiségében, méreteiben mutatkozik meg, tehát nem abban, hogy szinte az egész világra kiterjedően, voltaképp saját keretein belül birodalmakat, városállamokat és kialakulóban lévő „nemzetállamokat” ölel fel, hanem abban, hogy „,nagyobb, mint bármely jogilag meghatározott politikai egység”, és az új „világgazdaságon” belül „...a rend- 
Baranyi Béla: Gondolatok a perifériaképződés történeti előzményeiröl és következményeiről.

Tér és Társadalom, 18. 2004. 2. 1-21. p.

2 Baranyi Béla

TÉT XVIII. évf. 2004 - 2

szer részei között az alapvető kapcsolat gazdasági...", kiegészülve az azt erősítő politikai, kulturális és egyéb szövetségi kapcsolatokkal (Wallerstein 1983, 27).

A modern világgazdasági rendszer kiindulópontjaként, s mintegy elöképeként, a tökés termelési mód alapján létrejött ,európai világgazdaság” meröben új helyzetet teremtett az európai munkamegosztás korábban kialakult rendjében, s következésképpen más módon érintette Európa különböző részeit, mindenekelött a kontinens nyugati és keleti felét, köztük az egykori Magyar Királyság területét. A 16. században lejátszódott folyamatok szinte máig ható következménnyel jártak Magyarország számára, föleg ami a kontinensen belüli centrum-periféria viszony kialakulásának a feltételeit illeti. A centrum-periféria elméletek föként a tökés viszonyokat elemzik, és többnyire a nemzetközi méretủ gazdaságra vonatkoznak. A legkülönfélébb centrum-periféria elméletek képviselői között egyetértés mutatkozik a tekintetben, hogy a centrum és a perifériák viszonyrendszerében hosszú távon természetesen elmozdulás következhet be, az egykori centrumterületek válhatnak perifériákká és fordítva. ${ }^{2}$ Ez az ellentétes irányú mozgás természetesen a világgazdasági folyamatokat és - különösen a nemzetállamok létrejötte után - az egyes nemzetgazdaságok keretei között zajló folyamatokat is egyaránt jellemezheti (Berend T.-Ránki 1979; Szücs 1983; Wallerstein 1983; Linge 1988; Barta 1990; Nemes Nagy 1990; 1996; Horváth 1998; Enyedi 2003).

A fentiek elörebocsátása után joggal tehetö fel viszont a kérdés, hogy történelmi előzményeit és következményeit tekintve hogyan érintette Magyarországot a 16. században kialakuló új világgazdasági rend? Nyilvánvaló, hogy a kezdetek Magyarország esetében is a 16. század elejére nyúlnak vissza. Ekkortól figyelhetö meg ugyanis az európai világgazdaság centrum- és periféria terïletei közötti megosztottság, az idők folyamán pedig egyre élesebben kirajzolódó ellentét, amely szorosan összefügg az Európa nyugati fele és keleti fele, némi leegyszerüsitéssel az Elbán inneni és Elbán túli területek közötti fejlődési irányvonal és sajátosságok elkülöniilésével, az európai munkamegosztásban betöltött szerep megváltozásával. Mindez természetesen évszázadokra kiható következményekkel Magyarország sorsát is gyökeresen befolyásolta. A nagy földrajzi felfedezéseket követỏen ugyanis gyökeres változások következtek be a kontinens két fele között. Az Elbától keletre fekvő területek (általánosabban Kelet-Európa), közöttük Magyarország kimaradtak a földrajzi felfedezések előnyeiből, miközben ennek következményeként elszenvedte azokat a hátrányokat, amelyek az Európát Elö-Ázsiával és Ázsiával összekötő szárazföldi kereskedelmi útvonalak megszünésével, a tengeri hajózási forgalom egykori európai centrumaikból (Hanza-városok, Földközi-tenger) a transzatlanti irányokba történő áthelyeződésével, valamint az árforradalom, illetve árrobbanás és a vele járó gabonakonjuktúra következtében az európai munkamegosztásban betöltött újfajta szerepkörrel járt együtt.

Az említett tényezők teljessé tették azt a folyamatot, amely a 14. és a 15. századi recesszióval kezdődött meg Európában, s amely azonban ellenkező eredményekre vezetett Kelet-Európában és Nyugat-Európában. Míg a változások NyugatEurópában a feudalizmus fokozatos leépülését és egy új, fejlettebb társadalmigazdasági alakulat, a tőkés rendszer kiépülését, $s$ nem utolsó sorban a gazdasági modemizáció kezdeteit jelentette, addig Kelet-Európában megrekedtek az addigi 
Baranyi Béla: Gondolatok a perifériaképződés történeti előzményeiröl és következményeiröl. Tér és Társadalom, 18. 2004. 2. 1-21. p.

TÉT XVIII. évf. 2004 『 2 Gondolatok a perifériaképzödés ...

3

modernizációs folyamatok, az Elbán inneni területek kikerültek a korábbi viszonylag egységes és töretlen gazdasági-társadalmi folyamatok fỏ áramából, a sok tekintetben Nyugat-Európához hasonlítható korábbi fejlődés megakadt, a feudalizmus újfent megerősödött. Kelet-Európa kiterjedt területei, részben az új európai munkamegosztás által ráhárított szerep miatt, az iparosodó Nyugat nyersanyagszállítójává, mezőgazdasági termékek, mindenekelőtt gabonaexportőrévé - Európán belül gazdaságilag kvázi gyarmati szerepkört játszó tényezöjévé - vált, miközben az egyéb történelmi körülmények (pl. Magyarország és a tóle délre és délkeletre fekvô területek esetében a török hódoltság; a városfejlödés nyugat- és kelet-európai különbözöségei stb.) miatt sor került a refeudalizációra, a feudális rendszer ,újrakiadására”, a majorsági gazdálkodás ismételt megerősödésére, az ezzel járó „,zweite Leibeigenschaft", azaz a "második jobbágyság" újbóli intézményesülésére, a nyugat- és kelet-európai fejlödés hosszú távú szétválására, végsősoron KeletEurópának a fejlettebb centrumterületté váló Nyugathoz viszonyított perifériára szorulására (Pach 1961; 1968; Berend T.-Ránki 1972; Wallerstein 1983).

A nyugat-és kelet-európai fejlödési irány elkanyarodásának folyamatában Magyarország is a periferizálódó kelet-európai térség részévé vált. A török invázió által súlyosbított helyzetben pedig a 16. század első felétől egyre inkább nyilvánvalóvá vált Magyarország leszakadása Nyugat-Európához képest, holott a 15. század végéig a magyarországi rurális fejlödés irányvonala a nyugat-európaival alapvetően megegyezett (Pach 1966). A kérdéskör magyar vonatkozásait tárgyaló szakiroda$\operatorname{lom}^{3}$ túlnyomórészt megegyező álláspontja szerint, Magyarország a 16. század első felétől a centrum-periféria viszonyrendszerében évszázadokra Európa perifériájára szorult, magában hordozva a „,kelet-európaiságból” származó hắtrányos, sőt halmozottan hátrányos helyzet számos jellemzőjét. Az 1526-os mohácsi vész nem pusztán egy esemény volt a vesztett csaták sorában, hanem mintegy szimbolikus kifejeződése annak, hogy Magyarország fejlödése hosszú időre mellékvágányra siklott. Mohács ugyanis ,....kihatásában korszakot zár be: vele a középkor Magyarországának államegysége és függetlensége bukott el. Az 1514-ben elnyomott, a magyar urak és hódító törökök csapásaitól vérző népre a 'második jobbágyság' súlyos korszakának sötét fellege borult." (Molnár 1967, 158).

\section{Centrum-periféria viszonyrendszer nemzeti keretek között}

Kifejezetten Magyarországról szólva, a centrum-periféria fogalompár hosszú ideig meglehetősen relativizálódott. Magyarország önmaga is periféria vagy jobbik esetben félperiféria volt Közép-Kelet-Európa nyugattal éppen hogy érintkező részében. Maga az egész ország - ha lehet egyáltalán egyazon országnak tekinteni a mintegy 150 évig három részre szakadt Magyarországot - tulajdonképpen évszázadokon át az európai fejlődés föáramának perifériájára szorult, Nyugat-Európa félperifériájânak tekinthető. Ez természetesen nem jelenti azt, hogy a történeti Magyarország területén belül ne jöttek volna létre a centrum-periféria viszonyrendszer valamilyen formái, s ne történt volna perifériaképzödés. A folyamat azonban a 
Baranyi Béla: Gondolatok a perifériaképződés történeti előzményeiről és következményeiröl.

Tér és Társadalom, 18. 2004. 2. 1-21. p.

nyugat- és kelet-európai fejlödés ellentmondásaitól és dichotómiájától eltekintve jelentős mértékben a történeti múlt sajátosságaival, az ország helyzetét befolyásoló nemzetközi körülményekkel, s leginkább az ország török megszállás miatti hosszú időre szóló, három részre szakadásával függött össze.

Az amúgy is anorganikus gazdasági-társadalmi folyamatok következményeit súlyosbította az ország megosztottsága, a szilárd nemzetállami keretek létrejöttének elhúzódása. Ennek függvényében teljesen más megítélés alá esik a Habsburg fennhatóság alá eső Királyi Magyarország (Nyugat- és Észak-Magyarország, olykor a Partium), az Erdélyi Fejedelemség és a török hódoltság alá eső, főleg az alföldi területeket magában foglaló kiterjedt középső országrész. Nyilvánvalóan más-más gazdasági hatások érvényesültek a Királyi Magyarországon, ahol számos terület és város került a fejlettebb osztrák birodalmi területek és városok vonzáskörébe, vagy éppen az Erdélyi Fejedelemségben, ahol átmeneti idökben a relatív függetlenség elönyeit élvezve a gazdasági fellendülés jelei mutatkoztak, s gazdaságilag is meglehetősen erős nagyvárosi decentrumok tevékenykedtek. De kevésbé mondható mindez el a török hódoltság alá eső területekröl, ahol a pusztulás és népességvesztés meglehetősen általános jelenségén túl inkább csak a khász birtokokon és egyikmásik, a függetlenségét megörizni képes, a későbbi alföldi parasztpolgárimezővárosi, illetve a fejlödés sajátos ,alföldi útját” járó alföldi város játszott jelentékeny centrum szerepet egy-egy térségben (Erdei é.n. 66-67; Féja é.n.).

Enyedi György újkeletú, definitív megfogalmazását ${ }^{4}$ irányadónak tekintve, a centrum-periféria viszonyrendszer komplex és egységes formában Magyarországon nagyjából a rendi (feudális) társadalom 1848-tól kezdődő összeomlása, illetve a nemzetállami keretek megszilárdulása a 19. század közepe és második fele, de leginkább a magyar gazdasági modernizáció - W. W. Rostow híres növekedéselméletére is tekintettel - a "nagy nekilendülés" (take-off $)^{5}$, ha mégoly felemásan és ellentmondásoktól terhelten is, az 1867. évi kiegyezést követöen, a dualizmus korában az Osztrák-Magyar Monarchia történetének közel félévszázada során bontakozott ki, amely egyben a polgári gazdaság és társadalom kiépülésének a lendületes időszaka volt. Míg ugyanis ezt megelőzően a Habsburg-ház ellen folytatott függetlenségi küzdelmek - köztük a legjelentősebb és legutolsó, az 1848-49-es szabadságharc -, és a politikai függetlenség hiánya lassította a polgári intézmények kialakulását és a gazdaság fellendülését, a dualizmus idején az „inga” Nyugat felé lendült, s az ország kezdett felzárkózni Nyugat-Európához (Rostow 1963; Beluszky 2002).

A dualizmus korában nyilvánvalóan más volt a szerepe a centrumot „koncentráltan", egyszersmind legkiteljesültebb formában megtestesítö fövárosnak (Budapest), az egyes nagy, mintegy „szigetszerüen” elhelyezkedő centrumvárosoknak (Pozsony, Kassa, Debrecen, Nagyvárad, Kolozsvár, Marosvásárhely, Arad, Temesvár, Brassó, Szabadka stb.), illetve a nagy történeti régióknak (pl. Alföld, Dunántúl, Felvidék, Erdély, Délvidék). A nagyrégiók viszonylatában és az egyes régiókon belül természetesen számos összefüggésében értelmezhető a centrum-periféria viszony. Voltak eleve hátrányos helyzetủ térségek, mint pl. az Alföld, a Délvidék kiterjedtebb területei, Dél-Erdély egyes térségei, miközben különböző nagyvárosi 
Baranyi Béla: Gondolatok a perifériaképződés történeti előzményeiröl és következményeiről. Tér és Társadalom, 18. 2004. 2. 1-21. p.

TÉT XVIII. évf. 2004 - 2

Gondolatok a perifériaképzödés...

5

központok körül a gazdasági-társadalmi innovációkat magukban foglaló és magukhoz vonzó igen fejlett centrumvárosok tevékenykedtek hatalmas vonzásterülettel (Kassa, Brassó, Temesvár, Kolozsvár, Marosvásárhely). Számottevő súlyuk és szerepük volt a gazdasági kohézió valamifajta erősítésében az elsődleges nagy vásárváros-vonalak mentén húzódó területeknek. Ám minden pozitív megnyilvánulás ellenére „A társadalmi-gazdasági fejlettség területi színvonala nagy vonásokban a természeti-földrajzi nagytájak szerint alakult: a mezögazdasági termelésnek, különösen a konjukturális helyzetü gabonatermelésnek szükös feltételeket biztosító hegykeret (a Kárpátok), mind a gazdasági színvonala, mind az infrastruktúra (településfejlettség, közlekedési feltártság stb.), mind pedig a lakosság kulturális színvonala alapján hátrányos helyzetú terület volt" (Beluszky 2002, 73).

A nemzeti keretek között a 20. század fordulójára jelentös mértékben elörehaladt kohéziós tendenciákat, az országon belüli perifériák és az európai félperiférián elhelyezkedö Magyarország figyelemreméltó felzárkózási folyamatát Trianon és tragikus következményei törték meg újfent.

\section{Trianon és következményei}

A ma már csak 93 ezer négyzetkilométer területủ Magyarország létrejötte közismerten az I. világháborút lezáró trianoni békeszerződés következménye. Az 1920. június 4-én a trianoni békeszerződés által kikényszerített új államhatárok hosszú távra szólóan az egyik legnagyobb traumát váltották ki a magyarság évezredes történelmében. A Magyarország területét és népességét ért súlyos veszteségekre vonatkozó rideg tények széles körben ismertek. A szakirodalom kellő mélységgel foglalkozik azzal a tragikus szituációval, amely során Magyarország keleti, jórészt pedig az északi és déli határainak kialakításában meghatározó szerepet játszott a Kárpátok ívén belül elhelyezkedő, nagyrészt az Alföld szélén, a felvidéki Losonctól, egészen a délvidéki Zomborig futó, félkör alakú vasúthálózat, mintegy eleve elrendelve a trianoni határvonást. A stratégiailag rendkívül módon fölértékelt kérdés közvetlen okként és ürügyül szolgált a mind nagyobb területekre pályázó utódállamoknak ahhoz, hogy a kiemelkedő jelentőségủ vásárvonal mentén húzódó vasút legyen a trianoni határ kijelölésének a közvetlen meghatározója. Miután pedig a vasútvonal teljes hosszában magyarlakta területeken húzódott, szinte törvényszerú volt színmagyar területek elcsatolása is. Az ún. vasútszabta határok, a vasúti gyúrü határ menti tisztán magyar nyelvterületein közvetlenül mintegy 1,6 millió magyar elszakítását jelentették (L. Nagy 1965; Erdősi 1996; Romsics 2001; Majdán 2002; Palotás é.n.; Rónai é.n.).

A trianoni határok soha nem tapasztalt nehézségek elé állították a megcsonkult országot és a magyarságot. A Kárpát-medence politikai térképét átrajzoló Trianon egyik legsúlyosabb következménye mégis az volt, hogy az újonnan formálódott keleti határok már szervesen összetartozó, összekapcsolódott és egymásra épült gazdasági egységeket bomlasztottak fel. Ennek egyik látványos, és a határon átnyúló kapcsolatokat mindmáig hátráltató következménye, a gazdasági-társadalmi 
Baranyi Béla: Gondolatok a perifériaképződés történeti előzményeiröl és következményeiröl.

Tér és Társadalom, 18. 2004. 2. 1-21. p.

viszonyrendszerek szinte minden összetevőjét meghatározó térszerkezet széttöredezése, a határ menti kettös perifériahelyzet, a határmentiség és a halmozottan hátrányos helyzet együttes, egymást erösítő „,hatásmechanizmusának” a kialakulása volt. A kapitalizálódó Magyarországon a századforduló környékére kezdtek elkülönülni a regionális fejlödés magterületei, amelyek zavartalan fejlődés esetén idővel valódi régiókká válhattak volna. A Kárpát-medencét keresztül-kasul átszelö, új politikai határok azonban szétdarabolták a 19. század végére, a 20. század elejére körvonalozódó régiókezdeményeket (1. ábra). Az új határok amellett, hogy szervesen formálódó régiókat érintettek, az interregionális és a magyar-magyar kapcsolatokat lehetetlenné tették, s magát a határforgalmat is rendkívüli módon megnehezítették (Ruttkay 1995; Tóth 1996; Tóth-Golobics 1996; Golobics-Tóth 1999; Rechnitzer 1999).

\section{1. ÁBRA}

A Kárpát-medence régiói

(Regions of the Carpathian Basin)

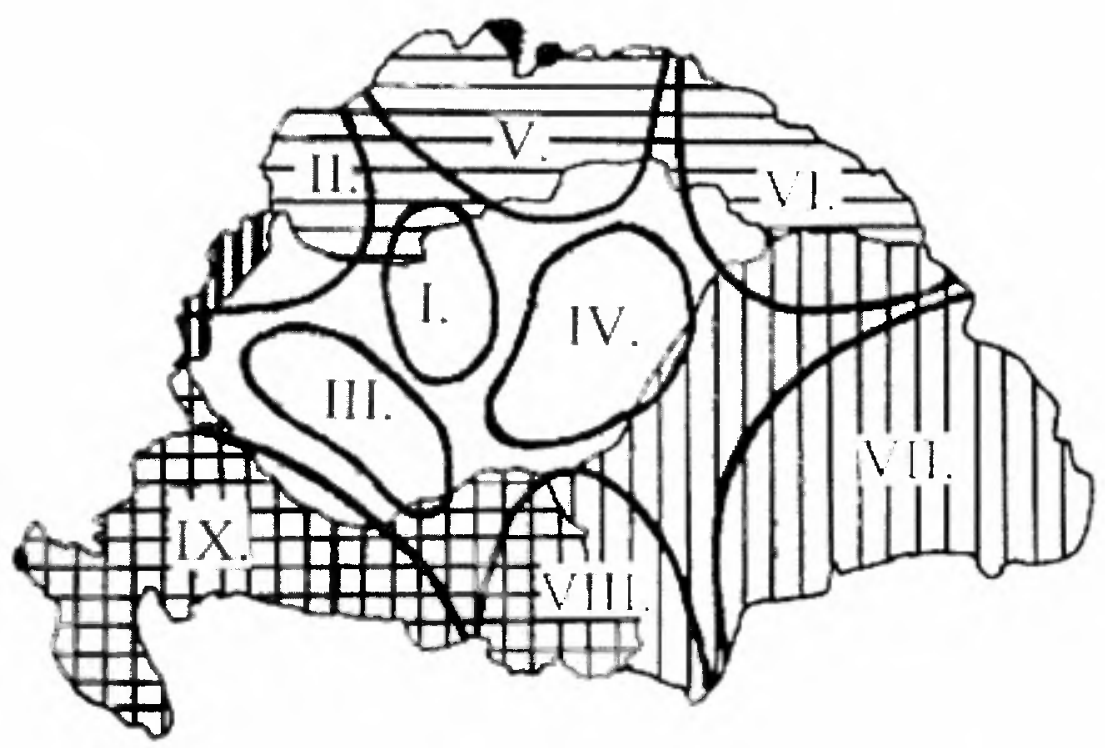

Jelmagyarázat: I.--IX.: régiókezdemények.

Forrás: Tóth-Golobics ábrája nyomán részben átszerkesztve.

A Kárpát-medencében azonban a két világháború között az egymással szembenálló államok ellenséges légköre sem kedvezett az államhatárokon átnyúló regionális együttmúködéseknek. Az ellenséges szomszédi viszony lehetetlenné tette a gazdasági jellegü kapcsolatokat a határokon ,kívül rekedt” nagyvárosok és a Magyarországon maradt, központjukat vesztett egykori vonzáskörzeteik között. A trianoni határváltozások miatt az Alföldön jóval nagyobb területek vesztették el korábbi vonzásközpontjukat, mint az ország északi vagy nyugati részén. Ez abból adódott, hogy az alföldi jelleg következtében itt kevesebb, viszont jóval nagyobb népességü 
Baranyi Béla: Gondolatok a perifériaképződés történeti előzményeiröl és következményeiröl.

Tér és Társadalom, 18. 2004. 2. 1-21. p.

TÉT XVIII. évf. 2004 - 2

Gondolatok a perifériaképzödés ...

7

és kiterjedésü - tehát nagyobb vonzáskörzetü - város helyezkedett el, mint az ország más területein. Következésképpen a központjaikat veszített alföldi területeknek az új közigazgatási keretekbe történő integrációja igen nehézkes volt. A politikai államhatárok természeti tájakat és gazdaságföldrajzi egységeket szelve keresztül szétvágták a korábbi regionális kapcsolatokat. Az Alföld-peremi vásárvárosok és az azokat összekötő transzverzális közút- és vasútvonalak, valamint az egykori vonzásközpontok fejlett ellátó- és szolgáltató funkciókkal együtt történt elvesztése következtében a trianoni Magyarország államhatárai mentén jelentős városhiányos területek keletkeztek. Az új államterületeken belül pedig a demográfiai, gazdasági, igazgatási, településhálózati stb. értelemben fölöttébb túlsúlyossá vált Budapestnek

nem maradt versenytársa, miután a perifériákon nem funkcionáltak a történetileg kialakult regionális központok, kvázi „versenytársak”. Ily módon a Kárpátmedencén belüli politikai államhatárok között az egyes államok térszerkezete csak szerves folyamatokat fékezỏ politikai korlátok között fejlödhetett, a belső kapcsolatrendszer intenzitása és textúrája sokkal nagyobb, erősebb, illetve sürübb lett, mint a határ menti térségeké, nem is szólva a határon átívelö regionális együttmüködés fejlődésének a korlátairól. Eközben szinte törvényszerủ és intenzív folyamattá vált a határ menti sávban zajló sokirányú perifériaképzödés (Tóth 1996; TóthGolobics 1996; Hajdú 2001).

\section{Perifériák Magyarországon}

\section{Belsö perifériák}

A centrum-periféria viszonyrendszerben Magyarországon is a periférikus, hátrányos vagy a még rosszabb helyzetben lévő halmozottan hátrányos területektérségek, azaz a területi egyenlőtlenségeknek két nagyobb előfordulása jellemző napjainkban: az ún. belsö- és a külsö (határ menti) periféria. A belsö perifériák azok a jelentékenyebb kiterjedésủ térségek, amelyek az ország belső területein elhelyezkedve az átlagosnál koncentráltabban viselik magukon a hátrányos helyzet következményeit. Ezeket a „szigetszerüen” elhelyezkedő válságterületeket általában tartós gazdasági recesszió, akut foglalkoztatási válság, magas, az országos átlagot jóval meghaladó nagyságrendủ munkanélküliség, rossz infrastrukturális ellátottság, a centrumtelepülésektől és az egyéb decentrumoktól való nagy távolság, nehéz megközelíthetőség, elvándorlás, elnéptelenedés, szegénység, a roma népesség koncentrációja stb. jellemzi. Ilyen belsỏ perifériák nagy számban találhatók az ország különböző területein, többek között a Dunántúl déli felében a Tabi, Tamási és Lengyeltóti kistérség, illetve Nyugat-Dunántúlon a Vasvári kistérség, a Dél-alföldi régió néhány kistérségében (Kunszentmiklós, Kunszentmárton, Kistelek stb.), de leggyakoribb és legkiterjedtebb előfordulásuk általában az Alföld nagyrégióban, főként az Észak-alföldi és Észak-magyarországi régió összesen hat megyét magában foglaló, északkelet-magyarországi térségben tapasztalható. 
Baranyi Béla: Gondolatok a perifériaképződés történeti előzményeiről és következményeiröl.

Tér és Társadalom, 18. 2004. 2. 1-21. p.

8 Baranyi Béla

TÉT XVIII. évf. 2004 — 2

Az utóbbiakkal kapcsolatban úgy is lehetne fogalmazni, hogy Magyarországon belül tulajdonképpen az egész kelet-magyarországi térség, különösen pedig Északkelet-Magyarország gazdasági-társadalmi helyzete ma is periférikusnak minősül, s területén nagy számban fordulnak elỏ halmozottan hátrányos helyzetủ belső (Bodrogköz, Taktaköz, Közép-Tiszavidék, Bihar, Sárrét, Szatmár, Bereg, Cserehát stb.), illetve - részben az előbbiekből kikerülő - külső (határ menti) perifériák. Leegyszerúsítve azt lehetne mondani, hogy a Szeged-Szolnok-Balassagyarmat képzeletbeli vonaltól északra elhelyezkedő területek jelentős része az ország egyik legkiterjedtebb válságövezeteit foglalják magukban. De ilyen belső perifériák találhatók Tolna és Somogy találkozásánál, valamint Baranya északi felében. A belső perifériák nagyon gyakran érintkeznek, sőt egybeolvadnak a határ menti, ún. külsỏ perifériákkal (2. ábra).

\section{2. ÁBRA}

Magyarország 500 leghátrányosabb helyzetben lévö települése a regisztrált munkanélküliség szintje alapján (2002. augusztus)

(The Most Disadvantageous 500 Settlements in Hungary by the Unemployment Rate, Aug 2000)

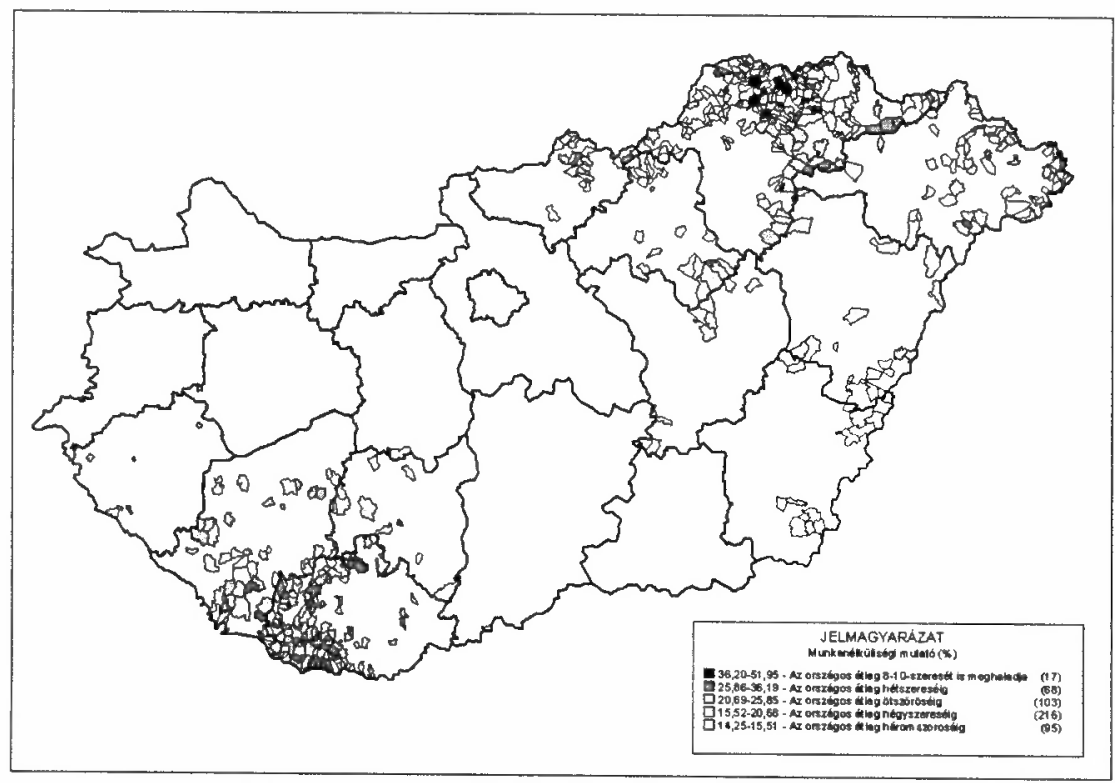

Forrás: Foglalkoztatási Hivatal adatai alapján szerkesztette Balcsók I. MTA RKK ATI Debreceni Osztály.

\section{Külsö perifériák: határmentiség és perifériahelyzet}

A történettudomány, a gazdaságtörténet és a területi tudományok mủvelői számára régtől fogva bizonyított, $\mathrm{s}$ az érdeklődők szélesebb körében is nyilvánvaló tény ma már, hogy a határ menti periférikus területek kialakulása a trianoni békekötéssel 
Baranyi Béla: Gondolatok a perifériaképződés történeti előzményeiről és következményeiről.

Tér és Társadalom, 18. 2004. 2. 1-21. p.

TÉT XVIII. évf. 2004 - 2

Gondolatok a perifériaképzödés ...

9

vette kezdetét. A történelmi Magyarország drasztikus területi feldarabolásával együtt járó határok meghúzását követően az ország új határai mentén, váltakozó szélességben, egy olyan elmaradott rurális övezet kialakulása kezdödött meg, amely jórészt a megmaradt megyecsonkokból képződött. Az országot övező határszakaszok túlnyomó többségében a perifériahelyzettel, azaz a halmozottan hátrányos helyzettel illusztrálható. A határ menti települések a trianoni döntést követöen, akaratukon kívül egyik pillanatról a másikra kettős értelemben is perifériákká váltak. Ez egyfelől azt jelentette, hogy a korábbi országon belüli, úgymond „mélységi” elhelyezkedésből egy - elválasztó szerepet betöltő - új politikai államhatár „szélére" szorultak, másfelől pedig elveszítették egykori, a határ túloldalára szakadt természetes vonzáscentrumukat, ami újfent a perifériahelyzet akkumulációját idézte elő. Ezek a határ menti területek Trianon után kevésbé voltak képesek integrálódni az ország gazdasági életébe, alig tudtak - és tudnak - bekapcsolódni a területi munkamegosztásba, s a keleti határmentének pedig ma is alig van kapcsolata a szomszédos országokkal, a határon túl fekvő jelentősebb városokkal, hiszen a határrégiók között nagy különbségek alakulhatnak ki. Az alapvetỏ okok sorában említhetô a centrum-periféria viszony alakulása, amely a nagyobb és kisebb térszerkezeti mozgásokra, valamint a határok két oldalán érintkező térségek gazdasági és társadalmi jellegében rejlö különbségekre vezethetők vissza (Ruttkay 1995; Rechnitzer 1997).

A határmentiség és a perifériahelyzet összefüggéseinek felismerése és az ezzel kapcsolatos kutatások nem új keletūek. A trianoni békeszerződés értékelése kapcsán politikai-etnikai szempontból már sokan és sokoldalúan vizsgálták a perifériaképződés kérdését, de gazdasági-társadalmi szempontból elsősorban csak a nyolcvanas évek elejétől-derekától figyelt jobban oda a hazai szakmai közösség, főleg a formálódó regionális tudomány képviselöi. A határmentiség kapcsán a hazai szakirodalomban több mint két évtizede találni már utalást a nemzetközi integráció lehetőségére (Enyedi 1976), mint a határ menti halmozódottan hátrányos helyzet sajátosságaira (Varga 1982). Egy újabb korai, a centrum-periféria fogalompár összefüggéseit alaposan és sokoldalúan tárgyaló tanulmány az Alföld régió határ menti területeinek vizsgálatakor pedig nemcsak a nagyrégió periféria-jellege, hanem határ menti területein a határmentiség és perifériajelleg között is rendkívül szoros összefüggéseket lát, amelyet adatokkal és empirikus vizsgálatokkal is sikerült alátámasztania (Tóth-Csatári 1983).

A határkutatás - benne kiemelten szereplö határmentiség és perifériahelyzet vizsgálatának korszakos állomása volt az 1986 novemberében Szombathelyen, az MTA RKK szervezésében tartott tudományos tanácskozás, amelynek számos előadója a határmentiség és döntően a periférikus helyzet összefüggéseit vizsgálta a kötetté szerkesztett elöadásaikban (Erdösi-Tóth 1988). Nem egy közülük (Erdösi F., Tóth J., Frisnyák $S$.) a centrum-periféria ellentét- és fogalompár kapcsán a határ menti területek, föként az alföldi nagyrégió esetében a nagyon szemléletes „periféria perifériái" kifejezést használta. A kifejezés elsősorban az Alföld és a határ mente, értelemszerủen mindenekelött a Magyarország keleti határaira vonatkoztatva született meg, abban az összfüggésben, hogy ha az alföldi nagytáj periféria, akkor e 
Baranyi Béla: Gondolatok a perifériaképződés történeti előzményeiről és következményeiröl.

Tér és Társadalom, 18. 2004. 2. 1-21. p.

régió gazdaságilag elmaradott kiterjedt térségei és mikrokörzetei egyenest a „periféria perifériái” lettek. A korábbi, a határmentiséget speciális (demográfiai, szociológiai, rurális) összefüggésekben tárgyaló tanulmányok (Kocsis 1988; Rechnitzer 1990; Kovács 1993;) után - mind a mai napig - egyre több munka elemzi a határmentiség és a centrum-periféria ellentét- és fogalompár sajátosságait.

Ma főként azok a határzónák számítanak perifériának, amelyek az ország elmaradott területeinek, régióinak a „szélén” helyezkednek el, s ahol gazdaságilagtársadalmilag elmaradott, hátrányos, nemegyszer halmozottan hátrányos helyzetü térségek, települések és településcsoportok érintkeznek egymással, voltaképpen perifériák találkoznak perifériákkal (Hardi 2000). Így váltak tulajdonképpen kettős perifériává a kelet-szlovák, az ukrán és részben a román határ menti térségek. De a horizontot kitágítva a keletröl szomszédos hatalmas kiterjedésü térség egészében is könnyen felismerhetök egy összefüggő, öt kelet-európai országot (Lengyelország, Szlovákia, Magyarország, Románia, Ukrajna) átfogó tartós, azonos jeleket mutató periférikus helyzetü nagyrégió jegyei (Gorzelak 1998). Tovább bonyolítja a helyzetet és hozzájárul a perifériaképzödéshez az is, hogy a térség államhatárai mentén jelentős nemzetiségi problémák is mutatkoznak (Illés 2002).

Az elöbbiekkel összhangban megfogalmazható tehát a következtetés, hogy ha Magyarország egészén belül az Alföld helyzete periférikusnak minősül, akkor a keleti, de különösképpen az északkelet-alföldi határszél halmozottan hátrányos helyzete miatt joggal érdemelte ki a ,periféria perifériája" megnevezést. Ezt a 10-20 km széles sávot a megyeközpontok gyenge vonzása, a fejletlen infrastrukturális állapotok, a rossz elérhetőség, a nagy volumenủ munkanélküliség, a roma népesség magas aránya és a kedvezötlen természeti adottságok (gyenge termöképességủ talajok, ár- és belvízveszély) jellemzik. Aligha véletlen, hogy a magyarromán és a magyar-ukrán határ mente kialakulása - tulajdonképpen Trianon - óta összességében hátrányos helyzetủ térségnek számított, s ma Magyarország egyik legkiterjedtebb válságövezeteinek egyike (Enyedi 1996).

Nem kétséges tehát, hogy a kelet-magyarországi államhatárok két oldalát alkotó határrégiók számottevő része ma is elmaradott terület. A részben történeti, részben pedig az ugyancsak korábbi kedvezőtlen makro- és mikrogazdasági tényezők és hatások következményei, az életképes gazdasági programok hiánya, az elavult infrastrukturális és közlekedési rendszerek, s föként pedig a minden területen fölöttébb vontatottan fejlődő határon átívelö kapcsolatok miatt Magyarország és szomszédai számára egyaránt létfontosságú kérdés a határmentiség és a határon átnyúló együttmüködés ügye. A ma még inkább csak hátrányokat magában foglaló határ menti fekvés a marginális helyzetü térségek, települések fejlesztését és felzárkóztatását sürgetik, felkészülve az EU-integráció kihívásaira, a schengeni „,határvonással" együtt járó helyzet kezelésére (Baranyi 1999; 2002).

Magyarország jelenlegi északkeleti és keleti államhatárai mellett húzódó, az északi és keleti stratégiai kapcsolódási irányokhoz tartozó magyar-szlovák-ukrán-román, valamint a déli stratégiai kapcsolódási pontoknál elhelyezkedö magyar-szerbhorvát határrégiók közös jellemzője a perifériajelleg dominanciája, annak minden 
Baranyi Béla: Gondolatok a perifériaképződés történeti előzményeiről és következményeiről.

Tér és Társadalom, 18. 2004. 2. 1-21. p.

TÉT XVIII. évf. 2004 — 2

Gondolatok a perifériaképzödés ...

11

gazdasági-társadalmi-kulturális hátrányával együtt. A felsorolt határrégiók közül különösen az északkelet-magyarországi és a dél-magyarországi határok mentén találhatóak az öröklött történeti-etnikai problémákon túl, nem utolsósorban Trianon következményeként, a gazdasági térszerkezet szétesése miatt ma is azok a túlnyomórészt peremterületek, amelyek jelentős mértékben periférikus, elmaradott térségeket foglalnak magukban a határok mindkét oldalán. Ez az elmúlt évtizedekben inkább erősödö, mintsem gyengülő halmozottan hátrányos helyzet az északkeletmagyarországi magyar-szlovák-ukrán-román, valamint magyar-szerb-horvát viszonylatban súlyosabb, a délkelet-alföldi magyar-román és az északnyugati magyar-szlovák térségben kevésbé súlyos gond, míg a magyar-osztrák határ mentén egyre kevesebb területi egyenlötlenség mutatkozik. A perifériahelyzet szempontjából legproblematikusabb területek Magyarország északkeleti, részben a délbaranyai határtérségei, amelyek egészében véve magukban hordozzák a peremvidéki, elzárt térség tragikus elmaradottságát, míg a román határszakasz lényegében annak a nagyrégiónak, az Alföldnek a sajátosságait tükrözi, amelyet határol, de a kevésbé domináns perifériajelleg létrejöttében az Alföld gazdasági problémáin túl mégiscsak fontos szerephez jutott a határmentiség (Ruttkay 1995; Rechnitzer 1999).

Igaz ugyanakkor az is, hogy amennyiben egy adott terület az államhatár mentén fekszik, az önmagában még nem jelent feltétlenül hátrányt, sőt bizonyos esetekben (pl. Nyugat-Európában) kifejezetten elönyös is lehet. Egyet lehet azonban érteni azzal az állásponttal, amely szerint ,Kétségtelen, hogy valamely terület határ menti fekvése nem jelent szükségszerüen periféria-jelleget, bár a két minősítés közötti egybeesés több mint véletlen" (Tóth-Csatári 1983). Mindazonáltal aligha vitatható, hogy Kelet-Magyarország esetében a határmentiség Trianon óta - részben a perifériaképződés miatt - mind a mai napig általában elmaradottságot jelent. Ezen a tájon a határok elválasztó szerepe még ma is eröteljesebben érvényesuil, mint a valós nemzeti érdekeket hatékonyan szolgáló összekötỏ (híd) szerep. A határok annyira áhított spiritualizálódása jelenleg is inkább csak kívánt cél, semmint valóság.

\section{Perifériaképzödés az Alföldön}

Jóllehet belső- és külső perifériák számos helyen találhatók az országban, legjellemzőbb módon, legnagyobb számban és legkiterjedtebb formában azonban az Alföldön fordulnak elö. A elmondottakon túl a perifériaképzödés szempontjából az Alföld nemcsak a történelmi elözményeket, hanem a történelmi folyamatok következményeit és a perifériaképződés, ha tetszik rendszerváltozás utáni és jelenlegi sajátosságait is talán a legtípusosabban jeleníti meg. Mindezt azért is fontos előrebocsátani, mert Magyarország keleti felében a rendszerváltást követỏ évtizedben a tulajdoni, a képzettségi-kulturális, foglalkoztatottsági, demográfiai, egészségügyi, szociális viszonyokban a társadalmi és a területi különbségek nem csökkentek, söt számottevően növekedtek. A strukturális és tradicionális hátrányokkal küzdő térségekben jelentős társadalmi, gazdasági és területi belsö differenciálódás ment végbe, 
Baranyi Béla: Gondolatok a perifériaképződés történeti előzményeiröl és következményeiről.

Tér és Társadalom, 18. 2004. 2. 1-21. p.

valamint a fejlettebb régiókhoz, kistérségekhez és településekhez képest számos (gazdasági, infrastrukturális, szociális) területen leszakadás következett be, miközben problémák is keletkeztek, újrateremtődtek különféle új egyenlötlenségek, különösen ami az akut foglalkoztatottsági válságot illeti.

Az Alföld-problematika ơsszefüggésének a vizsgálata önmagában is nagy jelentőséggel bír, hiszen térbeli kiterjedését tekintve a legnagyobb összefüggő természeti (földrajzi, ökológiai) tájunkról van szó, amely az ország területének közel 40\%-át teszi ki, s mintegy három millió embernek nyújt otthont. Ám a természetigazdasági, de legalább ennyire történelmi képzödmény iránt a jelenleg megnyilvánuló sokirányú érdeklödést mégsem csupán a tekintélyes kiterjedés, sokkal inkább a régió sajátos, a többitöl gyökeresen eltérő, mondhatni csöppet sem szokványos fejlödési útja, ,,mássága” kelti fel, amelyet újabban a területi tudományok mủvelöi körében egyre gyakrabban szokás „,Alföld-jelenség”, „Alföld-szindróma”, ,Alföldtünetcsoport", vagy egyszerüen csak ,alföldi út" kifejezésekkel illetni (Beluszky 1992; 1994; Csatári 1993; 1994).

A társadalmi-gazdasági fejlödés sajátosságainak a megitélését illetően ma már meglehetösen nagy a kutatók között a nézetazonosság, különösen ami a társadalmi folyamatok feltételrendszerének és jellegének az alakulását illeti, hiszen az „Alföldszindróma" már jól ismert történelmi tünetei az Alföld társadalmában zajló változásokat befolyásolták a legkarakterisztikusabban. Az Alföld-jelenség legjellemzőbb megnyilvánulásai többek között a sokszínü másság; a fejlettség elemeit is magában hordozó elmaradottság; a természeti táj és a társadalomfejlődés szoros kölcsönhatásaként kialakult jellegzetes ,lelki kapcsolat” és „táji mentalitás”; az Alföld sajátos társadalmi struktúrát formáló pusztai, frontier jellege, (amely elsősorban társadalmi képlet, s csak azután területfejlödési típus); az Alföld periféria-jellege, sőt egyes kiterjedt térségeinek a „periféria perifériája” helyzete; a gazdaság és társadalom változásainak diszharmóniájában, a társadalmi és gazdasági fejlettség meg nem felelésében testet öltő sajátos társadalomfejlődési út: a paraszti polgárosodás, illetöleg a parasztpolgári-mezővárosi fejlődés; az egyedülálló alföldi település- és városfejlödés, s egyáltalán az ,alföldi út” megannyi más, egyedi vonása (Beluszky 1992).

A társadalmi fejlődés előbb leírt, történelmileg kialakult sajátos „alföldi útja”, amely egyszerre viselte magán az elmaradottság és a viszonylagos fejlettség jegyeit, az elmúlt félévszázad tơrténelmi-gazdasági-társadalmi változásai során megrekedt. Az egykori kettös fejlödés, az alföldi társadalom „másságának” korábbi alapjai, mindenekelött az Alföld ,történelmi szindrómái" közül is a legértékesebb tényezök a parasztpolgári-mezövárosi fejlődés finomszerkezetú mủködése, a relatíve fejlett mezővárosi intézményhálózat, a szabad menetelú jobbágyság lehetősége, a reformált egyház haladó-polgári irányzatainak a jelenléte, a nagyfokú társadalmi mobilitás, az „innovatív” paraszti mentalitás stb. kedvező hatásai az elmúlt félévszázad során mára megszüntek. A tájszeretö mentalitáson és identitáson kívül jobbadán ma már egyetlen olyan társadalmi tényező sincs, amely a korábbiakhoz hasonló kedvező társadalmi hatást tudna kiváltani az Alföldön. Azt lehet mondani, hogy a gazdaság és 
Baranyi Béla: Gondolatok a perifériaképződés történeti előzményeiröl és következményeiről.

Tér és Társadalom, 18. 2004. 2. 1-21. p.

TÉT XVIII. évf. 2004 @ 2

Gondolatok a perifériaképzödés ...

13

a társadalom fejlödésének végső soron az utóbbi számára előnyös diszharmóniáját immár a teljes „harmónia”, a korszerütlen gazdasági szerkezethez igazodó korszerủtlen társadalmi struktúra egymásnak megfelelése, sőt esetenként a korábbiakkal ellentétes előjelü, ezúttal már a társadalmi mozgásfolyamatok számára hátrányos diszharmónia váltotta fel (Beluszky 1992; Csatári 1993).

$\mathrm{Az}$ Alföld-problematika megítélésben természetesen akadnak nézetkülönbségek, hangsúlyeltolódások és vitatható álláspontok is. Meglehet, hogy az Alföld „másságáról” a fejlödés ,alföldi útjáról”, sajátosságairól, a „regionalista” kutató számára merőben szokatlan dolgok előfordulásáról beszélni történelmi időkben, de legalábbis egy évszázaddal korábbról jóval könnyebb, mint manapság. Ám az „alföldi út” kérdőjelei a jelenben is szép számmal megfogalmazhatók. Annál is inkább, mert az Alföld régió esetében a centrum-periféria hatásai által formált jellegzetes történetigazdasági-területi-települési-táji, s nem utolsósorban társadalmi fejlődés regionális különbözőségei sajátosan új megvilágításba kerültek a rendszerváltás nyomán (Baranyi 2000a; 2000b).

Melyek az újjáéledt, az ország területi fejlödésének „szétszakadásával”, de legalábbis a területi egyenlötlenségek növekedésével és a hátrányos helyzet további elmélyuullésével fenyegetö „Alföld-tünetcsoport” főbb jellemzöi, s melyek azok a társadalmi-gazdasági sajấtosságok, amelyek a gazdasági és társadalmi struktúraváltozások és mozgásfolyamatok tartalmát és minőségét döntően meghatározzák napjainkban? A feltételrendszer oldaláról vizsgálva a kérdést, könnyủ belátni, hogy a társadalmi folyamatok alakulását befolyásoló régi és újkeletủ tényezők sokaságából (pl. a hátrányos történelmi örökség következményei, a tradicionális mezögazdasági társadalomból öröklött jellegzetességek, a tanyarendszer, az ingázás, a szelektív vándorlás, a periféria-helyzet erősödése stb.) mindenképpen a gazdaság közelmúltbeli súlyos válsága a legfontosabb. Mindezek külön-külön és együtt is szerepet játszottak a specifikumok és területi differenciák létrejöttében.

Napjainkban a magyar gazdaság átalakulása újfent egy elmélyült területi válság körülményei között megy végbe. A területi válság alapvető jellemvonása az ország keleti részének „leszakadása”. Ennek egyik legnyilvánvalóbb jele, hogy KeletMagyarország megyéiben a gazdaság átalakulását súlyos munkanélkủliség kíséri. A munkanélküliek zöme a Budapest-Szolnok-Szeged vonaltól északra és keletre elterülő országrészen él, hiszen Kelet-Magyarországon alig találunk néhány olyan települést, ahol a munkanélküliségi ráta ne érné el az országos átlag legalább kétszeresét. Az itt lévő megyék (Szabolcs-Szatmár-Bereg, Borsod-Abaúj-Zemplén, Nógrád, Békés, Jász-Nagykun-Szolnok, Hajdú-Bihar) évek óta élen járnak a munkanélküliségi rangsorban. A munkanélküliségre vonatkozó adatok alapján is jól kirajzolódnak a területi egyenlőtlenségek, a külső- és belső periférikus területek nemcsak az Alföldre, hanem az egész országra vonatkozóan is (3. ábra). 
Baranyi Béla: Gondolatok a perifériaképződés történeti előzményeiröl és következményeiröl. Tér és Társadalom, 18. 2004. 2. 1-21. p.

\section{3. ÁBRA}

A relatív munkanélküliségi mutató alakulása Magyarországon településenként (2002. augusztus)

(The Development of the Relative Unemployment Rate in Hungary by Settlements, Aug 2000)

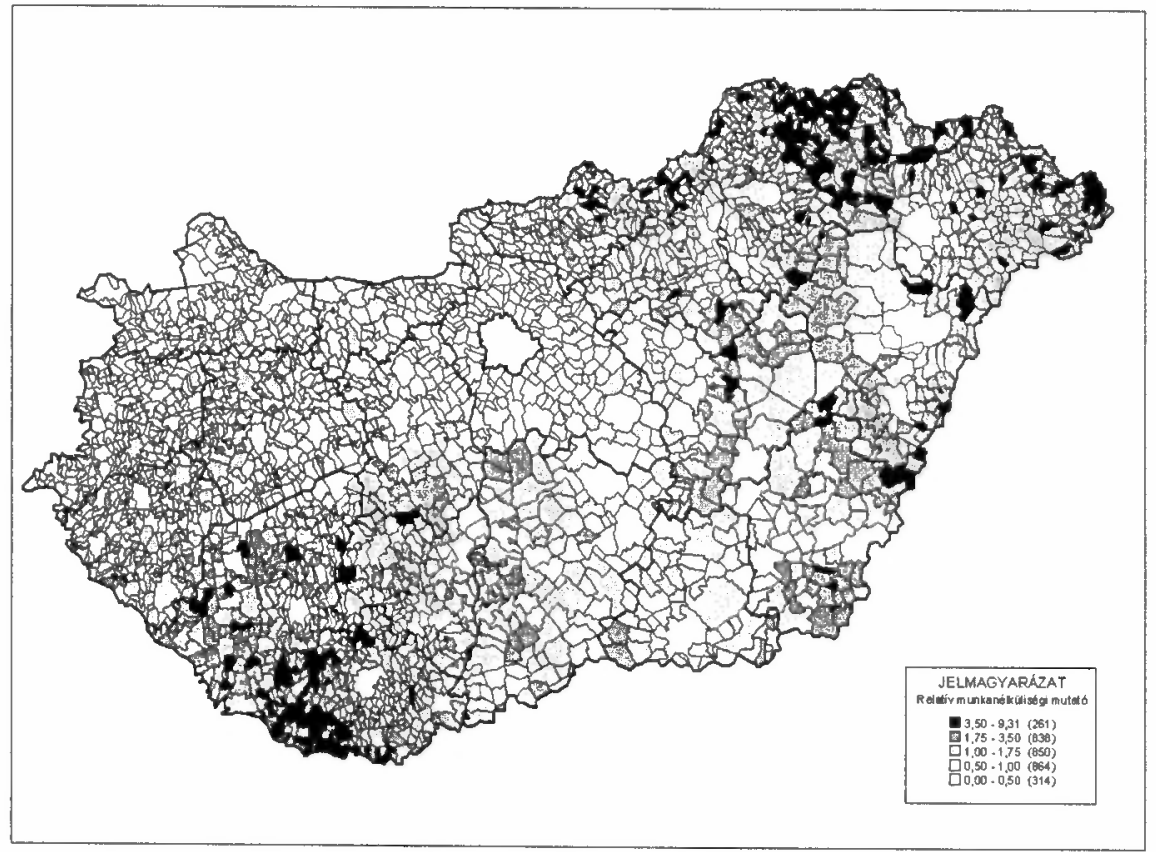

Forrás: Foglalkoztatási Hivatal adatai alapján szerkesztette Balcsók I. MTA RKK ATI Debreceni Osztály.

A gazdasági rendszerváltással együtt járó gyökeres tulajdoni, szerkezeti és szervezeti átalakulás sem javított a nagyrégióban elfoglalt helyzetén. A kiterjedt alföldi agrárterületek, rurális falusi térségek halmozottan hátrányos helyzete nem enyhültt. Az Alföld jelentös területei tovább periferizálodtak. A rendszerváltás során újraindult viszonylagos gazdasági-társadalmi dekoncentrációs folyamat igazi vesztesei mindenekelőtt az alföldi és keleti-északkeleti ország- és megyehatár mentén fekvő, elzárt és elmaradott falusi térségek lettek. A Budapestre és az ország ún. ipari tengelyére épült centrumokhoz képest az Alföld továbbra is periféria maradt, kiterjedt határ menti területek és ,szigethelyzetbe” szorult belsỏ térségek pedig egyenesen a „periféria perifériájává” váltak (Tóth 1988; Baranyi 1999; 2000a).

A területi egyenlötlenségek és a perifériaképződés legújabb kori, az államszocializmusban, illetve a rendszerváltás utáni alakulásának máris igen gazdag a szakirodalma ${ }^{7}$ Az ide tartozó munkák ok-okozati összefüggésrendszerbe ágyazva, 
Baranyi Béla: Gondolatok a perifériaképződés történeti előzményeiről és következményeiröl.

Tér és Társadalom, 18. 2004. 2. 1-21. p.

TÉT XVIII. évf. 2004 - 2

Gondolatok a perifériaképzödés ...

15

tulajdonképpen alátámasztják azt a kormányszintü, „hivatalosnak” is tekinthető állásfoglalást, amely a leghátrányosabb helyzetủ hatályos KSH kistérségekre vonatkozóan született, $\mathrm{s}$ amely plasztikusan ábrázolja a jelenlegi belsö- és külső perifériákat (4. ábra).

\section{4. ÁBRA}

A leghátrányosabb helyzetü 42 kistérség, 2003

(The Most Disadvantageous 42 Micro Regions, 2003)

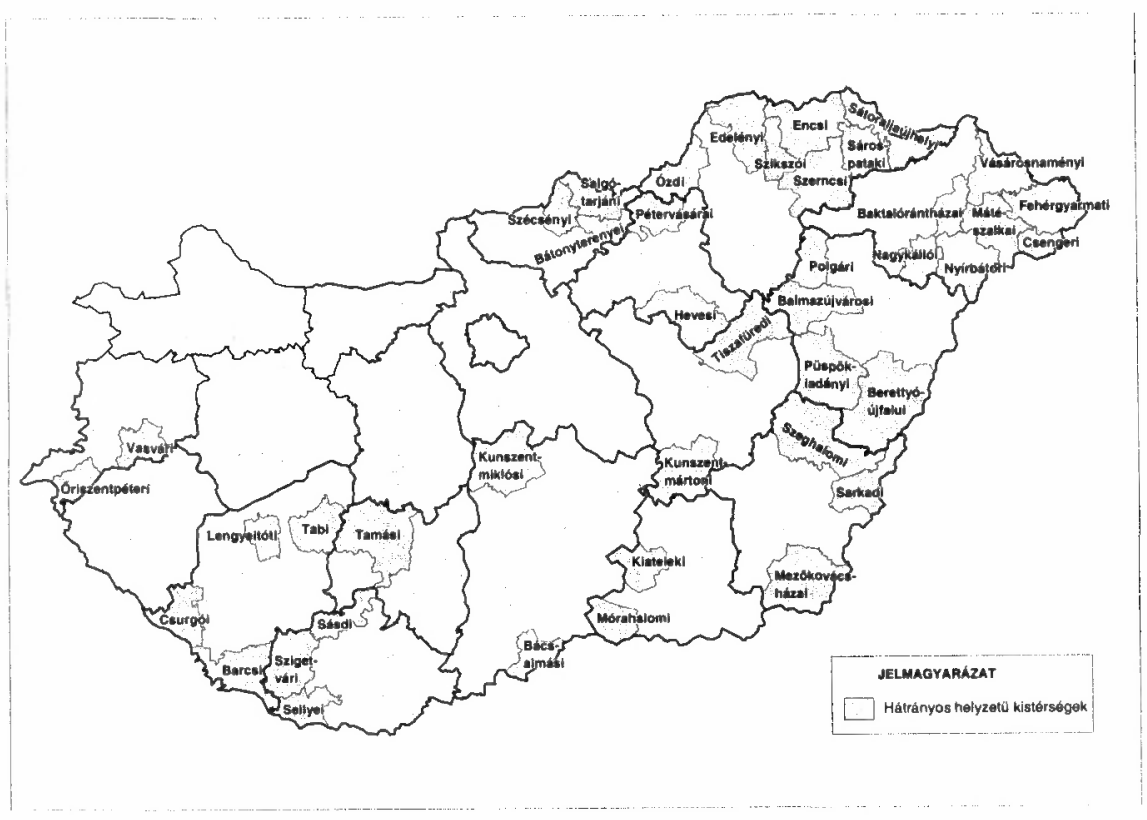

Forrâs: Saját szerkesztés a MEH Nemzeti Területfejlesztési Hivatal alapján.

Megközelítően hasonló kép rajzolódik ki a regionális tudomány szempontjai szerint, a különböző térségtípusokról készült térképi ábrázolás alapján. Jóllehet a jelenleg hatályos $150 \mathrm{KSH}$ kistérség besorolása ez esetben más szempontok, föként a gazdasági-társadalmi fejlödés iránya, illetve dinamikája - nem pedig az adott helyzet statikus leírása - szerint történt, mégis a periférikusnak tekinthető stagnáló kistérségek területi elhelyezkedése nagyjából megegyezik a kormányszintủ értékeléssel (5. ábra). 
Baranyi Béla: Gondolatok a perifériaképződés történeti előzményeiről és következményeiröl.

Tér és Társadalom, 18. 2004. 2. 1-21. p.

\section{5. ÁBRA}

A magyar kistérségek fejlettsége, 2003

(The Development Level of the Hungarian Micro Regions, 2003)

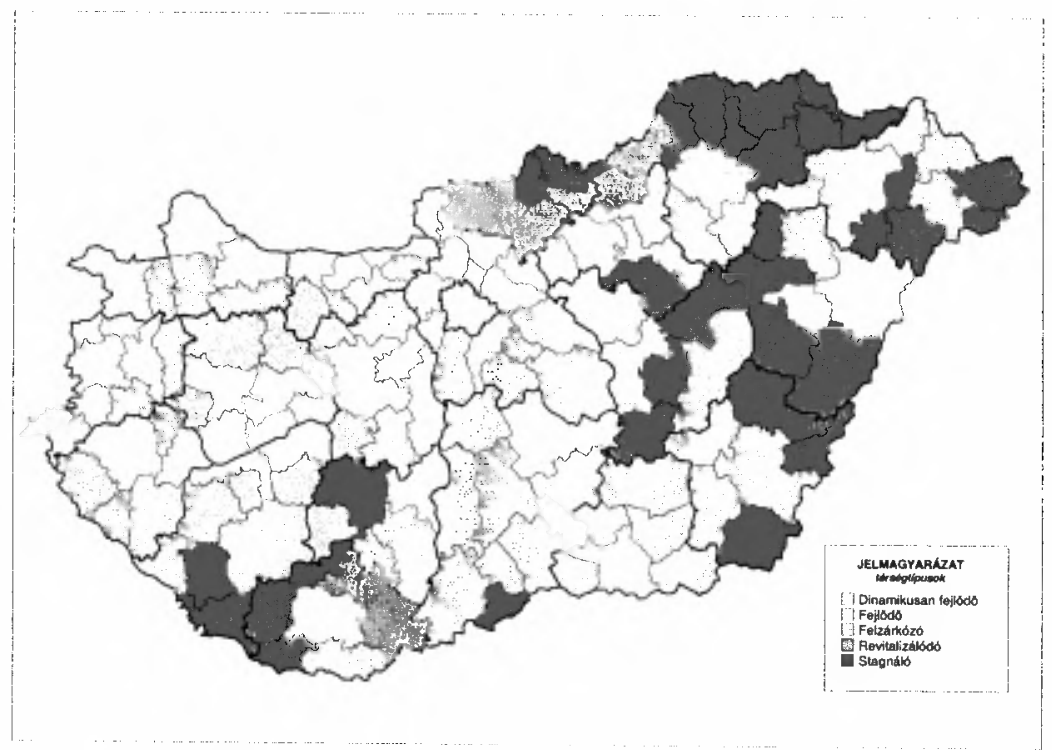

Forrás: Horváth-Szaló 2003.

\section{Összegzés}

Általánosabb érvénnyel, az ország más periférikus területeire vonatkozóan is elfogadható Enyedi Györgynek az a megállapítása, amely különösképpen az Alföldre vonatkozóan igaz, nevezetesen, hogy az Alföld története tulajdonképpen megkésettség egy megkésett országban, a félperiféria félperifériáján helyezkedve el, fejlettségi szintjét tekintve a térség ma is félperiférikus jellegü, valahol az Európai Unió peremvidékén (Enyedi 2003).

Mi várható tehát a jövöben? Amíg a kibontakozás és fellendülés oly annyira várt jelei számottevő mértékben megmutatkoznak, addig is szembe kell nézni a ma még lehangoló valósággal: az alföldi megyék-régiók jelenleg is az ország leghátrányosabb tájegységei-régiói közé tartoznak. Kényszerüen megszabadulva a rendszeres jövedelmet biztosító városi vagy falusi (tsz) állandó munkahelyektöl, az immár „kisvállalkozóvá előlépett” paraszti népesség még szorultabb helyzetbe került, mint az 1960-as és az 1970-es években, amikor tömegesen vált az ingázás „foglyává”. Tỏkehiánnyal és értékesítési gondokkal küszködve, megfelelö agrártámogatás és piac hiányában, a kis földterülettel rendelkező mezögazdasági „kényszervállalkozó” eleve vert helyzetben van az Alföld jelentös részén. Az igazi „kitörés” várhatóan csak keveseknek adatik majd meg. Egyre többen kerülhetnek közülük rövid időn belül a társadalmi-gazdasági élet perifériájára. Az elmondottak pedig a keleti 
Baranyi Béla: Gondolatok a perifériaképződés történeti előzményeiröl és következményeiről.

Tér és Társadalom, 18. 2004. 2. 1-21. p.

TÉT XVIII. évf. 2004 - 2

Gondolatok a perifériaképzödés...

17

országrész kiterjedt területeinek további társadalmi, egyszersmind területi léptékủ leszakadásához vezethetnek, és egy késöbb már nem, vagy csak óriási nehézségek árán visszafordítható folyamat felgyorsítói lehetnek, holott a kedvezőtlen folyamatok ellenében az Alföld lakossága - különösen a falvak népe - a gazdasági rendszerváltással együtt járó elönyök és hátrányok újfajta megosztását várja nemcsak egyes társadalmi csoportok és rétegek, hanem a különböző régiók között is.

Van-e e sély megmaradásra és a felzárkózásra? A kérdés és a megoldásokat kereső válasz elsősorban a munkanélküliség és foglalkoztatási viszonyok javítására, illetve a munkahelyteremtésnek a lehetőségeire vonatkozik, különösen az aprófalvas térségekben, ahol a munkaerőpiac problémái - annak ellenére, hogy ezekben a térségekben egyöntetüen magas munkanélküliség a jellemzö - eltérnek a más vidéki térségek foglalkoztatási gondjaitól. A legnagyobb különbségek a munkanélküliség és az elnéptelenedés, az elöregedés és az újranépesülés együttes jelenlétéből, valamint a munkaerő rendkívül alacsony koncentrálódásából, földrajzi szórtságából adódnak. Gondot jelent azonban a különféle értékek értékként való tudatosulásának és a hasznosításban használható innovációk terjedésének hiánya. Kérdés, hogy ezek a hiányok milyen mélyek, kívülröl hogyan lehet a folyamatokat kedvezően befolyásolni?

A hátrányos és periférikus helyzetủ rurális, erősen agrár jellegủ térségek kapcsán a fenntartható fejlődés esélyei föként azzal kecsegtetnek, hogy Magyarország uniós csatlakozása összességében hathatósan csökkentheti a meglévö területi egyenlőtlenségeket, enyhítheti a hátrányos-periférikus helyzetböl fakadó válságfolyamatokat, elösegítheti a periférikus térségek felzárkóztatását. Bizonyosnak látszik ma még, hogy a belsô- és külsö perifériákat érintöen hosszabb ideig a fenntartható fejlödés és a hanyatlás kombinációja fog érvényesưlni, bár a válság egyre kisebb léptékủ lesz, kistérségi szintủ marad, s a mezőgazdasági termelés hagyományos és modern elemeinek az ötvözése, a természet- és környezetvédelem, a falusi- és ökoturizmus révén is a fenntartható fejlődés sikeresen megvalósulhat. Ma még nyitott kérdés azonban, hogy mekkora részt foglalnak el a modern szerkezetü, de kicsiny eltartóképességủ térségek, s mekkora hányadot tesznek ki a hanyatló és alacsony életszínvonalat biztosító, fejlödésükben megrekedt falusi térségek.

Továbbra is kérdéses, hogy a centrum-periféria viszonyrendszer gyökeres megváltoztatásához mennyiben tudnak majd hozzájárulni az ország EU-csatlakozásától remélt elönyök, más szóval támogatások, amelyekre a magyar perifériák fölzárkóztatásának, a kohéziós politika eredményességének az elősegítéséhez fölöttébb szükség lesz, mert a periférikus térségek öneröböl nehezen vagy egyáltalán nem lesznek képesek kilábalni a tartós válságból.

\section{Jegyzetek}

\footnotetext{
${ }^{1}$ Wallerstein, I. kifejezése $(1983,27)$.
}

2 A centrum-periféria elméletekről részletes áttekintést nyújt Barta Györgyi tanulmánya (Barta 1990), amelyben igen helyesen állapítja meg többek között - a már idézett Wallerstein álláspontját erősítve -, hogy a centrum-periféria viszony a világban függőségi láncolatot alkot, amely egyrészt azt jelenti, hogy ugyanaz a térség (település) egy idöben lehet periféria és centrum is, másrészt azt, hogy az egyik 
térség fejlődése másutt az elmaradottság fokozódásával jár. Mint ahogy a szerzó által ugyancsak megidézett másik tanulmányra (Linge 1988) hivatkozva, a szerző a centrum-periféria lassan változó viszonyrendszerében helyesen világít rá, hogy egy-egy periférikus térség is centrummá válhat (Kanada, Japán), illetve a korábban inkább centrumhoz tartozó térségek is perifériára csúszhatnak, mint pl. egyes kelet-európai országok. A jelenkori európai regionális politika, a regionalizmus és a regionalizáció kérdéseit, a centrum-periféria viszonyrendszer európai és hazai összefüggéseit is érintve részletekbe menỏen elemzi Horváth Gyula kitünö monográfiája (Horváth 1998).

${ }^{3}$ A refeudalizáció és a második jobbágyság európai és magyarországi sajátosságaival foglalkozó gazdag szakirodalomból ld. többek között: Szabó (1940; 1976); Maksay (1958); Pach (1963); Varga (1969); Szücs (1983).

4 Enyedi György akadémikus felfogásában: „A centrum az a térség, amelyben a gazdasági-társadalmi innovációk (a technológiától az intézményi-szervezeti újításokig) megszulletnek; melynek következtében a térség gazdasága új, versenyelönnyel rendelkezỏ fejlődési szakaszra lép, s ennek eredményeként a térség társadalma is átalakul, jóléte nỏvekszik. Az újítások azután megkésve, gyakran módosulva, előnyeikból veszítve megjelennek a félperiférián; a perifériáig pedig el sem jutnak, vagy csak akkor, amikor már elavultak; a centrumban addigra új fejlődési modell formálódik." (Enyedi 2003, 1)

5 Ld. erról részletesebben Rostow (1963), illetve Ripp (1967).

A magyarországi nagy fellendülés, a gazdasági növekedés és modernizáció folyamatában sajátos elem volt Beluszky Pál álláspontja szerint ,az állam nagyfokú aktivitása, protekcionizmusa; ez a területi fejlödést is nagymértékben befolyásolta (állami kamatgaranciák a vasútépítéshez, a vasutak állami kézbe vétele, központi tarifapolitika kialakítása, az állami tulajdon magas aránya a gazdaságban, regionális adókedvezmények stb.)" (Beluszky 2002, 73).

Az ország két vagy három részre ,szakadásával”, különösen pedig az Alföld, azon belül a keleti megyék (Szaboles-Szatmár-Bereg, Hajdú-Bihar és részben Békés megye), valamint az északiészakkeleti országrész (Borsod-Abaúj-Zemplén, Nógrád megye) már-már drasztikus mértékú leszakadásával kapcsolatos nézetekkel már jóideje heves vitát folytat Enyedi György, mint az Alföld régió kapcsán is tette az 1993. évi elsö Alföld-kongresszuson (Enyedi 1994, 13-16). Álláspontját és érvelését természetesen el lehet fogadni, szó sincs „leszakadásról” (a szó önmagában is képzavar), ám a jelentôs területi differenciák és távolságok megléte nyilvánvaló. Ezzel kapcsolatban ld. még részletesebben Baranyi (2000a).

${ }^{7}$ Ld. tỏbbek kỏzött Szúcs (1983); Barta (1990); Miklóssy (1990); Nemes Nagy (1990; 1996); Beluszky (1990; 2002); Enyedi (1993; 1994; 1996; 2003).

\section{Irodalom}

Baranyi B. (1999) A „periféria perifériáján” - a határmentiség kérdőjelei egy vizsgálat tủkrében az Északkelet-Alföldön. - Tér és Társadalom. 4. 17-44. o.

Baranyi B. (2000a) Gondolatok a paraszti polgárosodás sajátosságairól és lehetséges terúleti típusairól az Alföldön. - Horváth Gy.-Rechnitzer J. (szerk.) Magyarország terïleti szerkezete és folyamatai az ezredfordulón. MTA Regionális Kutatások Központja, Pécs. 509-523. o.

Baranyi B. (2000b) A társadalmi szerkezet változásainak jellemzó vonásai napjainkban az Alföldön. Püski L.-Tímár L.-Valuch T. (szerk.) Politika, gazdaság és társadalom a XX. századi magyar történelemben II. KLTE Történelmi Intézet, Debrecen. 265-275. o.

Baranyi, B. (2002) Before Schengen - Ready for Schengen. Euroregional Organisations and New Interregional Formations at the Eastern Borders of Hungary. (Discussion Papers, 38.) Centre for Regional Studies, Pécs.

Barta Gy. (1990) Centrum-periféra folyamatok a magyar gazdaság területi fejlödésében? - Tóth J. (szerk.) Tér-idö-társadalom. MTA RKK, Pécs. 170-188. o.

Beluszky P. (1990) „Tradicionális” terủleti hátrányok és terápiájuk Magyarországon (1948-1992). Tóth J. (szerk.) Tér-idö-társadalom. MTA RKK, Pécs. 49-63. o.

Beluszky P. (1992) Az „Alfóld-szindróma” eredete (vázlat). - Vég kiârusítás I. Târsadalomföldrajzi Tanulmányok (1959-1992). MTA RKK, Budapest. 39-59. o.

Beluszky P. (1994) Alföldi út? Alföldi ösvények! - Tímár J. (szerk.) Az „alföldi uit” kérdőjelei. AlföldKongresszus, 1993. MTA RKK ATI Békéscsabai Osztály, Békéscsaba. 263-271. o.

Beluszky P. (2002) Teruleti hátrányok és ,kezelésuik” Magyarországon (1900)-1948-1991 - Vég kiârusítás II. Társadalomfödrajzi tanulmányok. MTA RKK, Pécs. 71-94. o. 
Baranyi Béla: Gondolatok a perifériaképződés történeti előzményeiről és következményeiröl.

Tér és Társadalom, 18. 2004. 2. 1-21. p.

Berend T.I.-Ránki Gy. (1972) A magyar gazdaság száz éve. Kossuth Könyvkiadó és Közgazdasági és Jogi Könyvkiadó, Budapest,

Berend T.I.-Ránki Gy. (1979) Gazdasági elmaradottság, kiutak és kudarcok a 19. századi Európában: az európai periféria az ipari forradalom korában. Közgazdasági és Jogi Könyvkiadó, Budapest.

Csatári B. (1993) Az Alföld tünetcsoport újraéledése 1990-1994. - Tér és Társadalom. 3-4. 1-12. o.

Csatári B. (1994) Az alföld-problematika fö kérdései, a regionális fejlődés esélyei és korlátai. - Tímár J. (szerk.) Az „alföldi út" kérdöjelei. Alföld-Kongresszus, 1993. MTA RKK ATI Békéscsabai Osztály, Békéscsaba. 79-83. o.

Enyedi Gy. (1976) Kelet-Közép-Európa gazdaságföldrajza. Közgazdasági és Jogi Könyvkiadó, Budapest.

Enyedi Gy. (1993) Társadalmi-területi egyenlötlenségek Magyarországon. Közgazdasági és Jogi Könyvkiadó, Budapest.

Enyedi Gy. (1994) Az Alföld fejlödésének perspektívái. - Tímár J. (szerk.) Az „alföldi út” kérdőjelei. Alföld-Kongresszus, 1993. MTA RKK ATI Békéscsabai Osztály, Békéscsaba. 13-16. o.

Enyedi Gy. (1996) Regionális folyamatok Magyarorszagon az átmenet idöszakában. Hilscher Rezsö Szociálpolitikai Egyesület, Budapest.

Enyedi Gy. (2003) Európa peremén? - A III. Alföld Kongresszuson (2003. november 28-29. Békéscsaba) elhangzott bevezetố előadás kézirata.

Erdei F. (é.n.) Futóhomok. Athenaeum, Budapest.

Erdősi F. (1996) A Kárpát-medence közlekedési hálózatának alakulása és nemzetközi kapcsolódásai. Frisnyák S. (szerk.) A Kárpát-medence történeti földrajza. MTA Szabolcs-Szatmár-Bereg Megyei Tudományos Testülete és a Bessenyei György Tanárképző Föiskola Földrajzi Tanszék, Nyíregyháza. 225-238. o.

Erdősi F.-Tóth J. (szerk.) (1988) A sajátos helyzetü térségek terület-és településfejlesztési problémái. Az 1986. november 4-5-én Szombathelyen tartott tudományos tanácskozás anyaga. MTA RKK; Ts-2/2 Program Iroda, Pécs.

Féja G. (é.n.) Viharsarok. Athenaeum, Budapest.

Golobics P.-Tóth J. (1999) A nemzetközi regionális együttmüködés és Magyarország térszerkezete. Tóth J.-Wilhelm Z. (szerk.) Változó környezetünk. Tiszteletkötet Fodor István professzor úr 60. születésnapjára. Janus Pannonius Tudományegyetem TTK Földrajzi Intézet, MTA RKK Dunántúli Tudományos Intézet, Pécs. 7-22. 0.

Gorzelak, G. (1998) Regional and Local Potential for Transformation In Poland. - Regional and Local Studies. 14. European Institute for Regional and Local Development, Warsaw.

Hajdú Z. (2001) Magyarország közigazgatási földrajza. Dialóg Campus, Budapest-Pécs.

Hardi T. (2000) Államhatárok és regionális együttmüködések. - Horváth Gy.-Rechnitzer J. (szerk.) Magyarország területi szerkezete és folyamatai az ezredfordulón. MTA Regionális Kutatások Központja, Pécs. 595-615. o.

Horváth Gy. (1998) Európai regionális politika. Dialóg Campus, Budapest-Pécs.

Horváth Gy.-Szaló P. (2003) Területfejlesztés és régiók. Regionális politika, strukturális eszközök koordinációja. - Európai Füzetek. 11. A Miniszterelnöki Hivatal Kormányzati Stratégiai Elemzö Központ és a Külügyminisztérium közös kiadványa, Budapest.

Illés I. (2002) Közép-és Délkelet-Európa az ezredfordulón. Átalakulás, integráció, régiók. Dialóg Campus, Budapest-Pécs.

Kocsis K. (1988) A határmenti fekvés hatása egy régió népesedési viszonyaira. A magyar-szlovák határvidék keleti részének népesedési folyamatai (1910-1980). - Földrajzi Értesítö. 1-4. 137-158. o.

Kovács, T. (1993) Borderland Situations It Is Seen by a Sociologist. (Discussion Papers, 18.) Centre for Regional Studies, Pécs.

Linge, G.J.R. (1988) Peripheralisation and Industrial Change. - Linge, G.J.R. (ed.) Peripheralisation and Industrial Change. Croom Helm, London, New York, Sydney. 1-22.

Majdán J. (2002) A vasút szerepe a határok kialakulásában. - Pásztor C. (szerk.) „... ahol a határ elválaszt" Trianon és következményei a Kárpát-medencében. Nógrád Megyei Levéltár, BalassagyarmatVárpalota. 100-115. o.

Maksay F. (1958) Parasztság és majorgazdálkodás a XVI. századi Magyarországon. Akadémiai Kiadó, Budapest.

Miklóssy E. (1990) Magyarország belső gyarmatosítása. - Tér és Társadalom. 2. 1-13. o.

Molnár E. (föszerk.) (1967) Magyarország története I. Gondolat, Budapest.

L. Nagy Zs. (1965) A párizsi békekonferencia és Magyarország 1918-1919. Kossuth Kiadó, Budapest.

Nemes Nagy J. (1990) Területi egyenlötlenségek dimenziói. Adalékok egy „kvázi-elmélethez”. - Tér és Tärsadalom. 2. 15-30. 0 .

Nemes Nagy J. (1996) Centrumok és perifériák a piacgazdasági átmenetben. - Földrajzi Közlemények. 1. 31-48. o. 
Baranyi Béla: Gondolatok a perifériaképződés történeti előzményeiről és következményeiröl.

Tér és Társadalom, 18. 2004. 2. 1-21. p.

Pach Zs.P. (1961) A magyarországi agrárfejlődés elkanyarodása a nyugattól. (A feudalizmusból a kapitalizmusba való átmenet magyarországi sajátosságainak kẻrdéséhez) - Agrártörténeti Szemle. 1-9. o.

Pach Zs.P. (1963) Nyugat-európai és magyar agrárfejlódés a XV-XVII. században. Budapest.

Pach, Zs.P. (1966) The Development of Feudal Rent in Hungary in the Fifteenth Century. - Economic History Review. 1. 13. 0.

Pach Zs.P. (1968) A nemzetközi kereskedelmi útvonalak XVI-XVII. századi áthelyezödésének kérdésében. - Századok. 5-6.

Palotás Z. (é.n.) A békeszerzödések katasztrofális következményei. Szenci Molnár Társaság.

Rechnitzer J. (szerk.) (1990) Nyitott határ. (A gazdasági és szellemi erôforrások innováció orientált fejlesztése az osztrák-magyar határ menti régiókban.) MTA RKK Nyugat-magyarországi Tudományos Intézet, Györ.

Rechnitzer J. (1997) Eurorégió vázlatok a magyar-osztrák-szlovák határ menti térségekben. - Tér és Társadalom. 2. 29-58. o.

Rechnitzer J. (1999) Határ menti együttmüködések Európában és Magyarországon. - Nárai M.Rechnitzer J. (szerk.) Elválaszt és összeköt - a határ. Társadalmi-gazdasági változások az osztrákmagyar határ menti térségekben. MTA Regionális Kutatások Központja, Pécs-Győr. 9-72. o.

Ripp G. (1967) A gazdasági növekedés szakaszai és az ipari társadalom elmélete. Kossuth Könyvkiadó, Budapest.

Romsics I. (2001) A trianoni békeszerzódés. Osiris, Budapest.

Rostow, W.W. (1963) The Economics of Take-off into Sustained Growth. London.

Rónai A. (é.n.) Fejezetek a politikai földrajzból. Püski Nyomda, Budapest.

Ruttkay É. (1995) Határok, határmentiség, regionális politika. - Comitatus. 12. 23-35. o.

Szabó I. (1940) A magyar parasżtság tơrténete. Budapest.

Szabó I. (1976) Jobbágyok - Parasztok. Értekezések a magyar parasztság történetéböl. Akadémiai Kiadó, Budapest.

Szücs J. (1983) Vázlat Európa három történeti régiojáról. Gondolat, Budapest.

Tóth J. (1988) Urbanizáció az Alfóldön. Akadémiai Kiadó, Budapest.

Tóth J. (1996) A Kárpát-medence és a nemzetközi regionális egyủttmükődés. - Pál Á.-Szónokyné Ancsin G. (szerk.) Határon innen - határon túl. JATE, JGYTF, Szeged. 27-43. o.

Tóth J.-Csatári B. (1983) Az Alfóld határmenti területeinek vizsgálata. - Területi Kutatások. 6. 78-92. o.

Tóth J.-Golobics P. (1996) Régiók és interregionális kapcsolatok a Kárpát-medencében. - A Kárpátmedence történeti földrajza. - Frisnyák S. (szerk.) A Kärpát-medence történeti fóldrajza. MTA Szabolcs-Szatmár-Bereg Megyei Tudományos Testulete és a Bessenyei György Tanárképzõ Föiskola Földrajzi Tanszék, Nyíregyháza. 107-119. o.

Varga J. (1969) Jobbágyrendszer a magyarországi feudalizmus kései századaiban. Budapest.

Varga D. (1982) Az ország peremén. Magvetó Kiadó, Budapest.

Wallerstein, I. (1983) A modern világgazdasági rendszer kialakulása. (A tökés mezőgazdaság és az európai világgazdaság eredete a XVI. században). Gondolat, Budapest.

\section{SOME THOUGHTS ABOUT THE HISTORICAL PRELIMINARIES AND CONSEQUENCES OF THE FORMATION OF PERIPHERIES}

\section{BÉLA BARANYI}

The essay, which also deals with universal historical correlations, introduces the historical preliminaries and the consequences of the formation of peripheries in Hungary. The author, by discussing the historical dimensions of the centre-periphery relations, gives an in-depth analysis of the characteristics of the inner peripheries (e.g. Bihar, Middle Tisza region, Szatmár, Cserehát, large areas of Somogy and Tolna counties etc.) and also of the outer (border region) peripheries. The author also explores, mostly using the example of the large region of the Great Hungarian Plain, the features of the backwardness, in some cases multiple deprivation. In the author's view, the history of the Great Hungarian Plain is actually the history of a belated development in a belated country: as regards the level of development, the larger part of East Hungary is semi-peripheral in character. The accession of Hungary to the European Union, 
Baranyi Béla: Gondolatok a perifériaképződés történeti előzményeiröl és következményeiröl.

Tér és Társadalom, 18. 2004. 2. 1-21. p.

TÉT XVIII. évf. 2004 匹 2

Gondolatok a perifériaképzödés ...

however, can decrease the existing territorial differences on the whole, alleviate the crisis phenomena coming from the backward situation and promote the catching up of the peripheral regions. Today it seems certain that a combination of sustainable development and decline will be typical in the inner and external peripheries for a longer time, although the crisis will be less and less significant, confined to the level of certain micro-regions. It remains an open question, however, how much the supports expected after the EU accession of Hungary will contribute to the fundamental transformation of the centre-periphery relations. These supports will nevertheless be crucial for the catching up of the Hungarian peripheries, because they will find it difficult or even impossible to get out of the long-term crisis on their own. 